\title{
Biocontrol of the root-knot nematode, Meloidogyne incognita, using an eco-friendly formulation from Bacillus subtilis, lab. and greenhouse studies
}

\author{
Aymen Ghnaam Basyony ${ }^{1}$ and Gaber Attia Abo-Zaid ${ }^{2^{*}}$ (D)
}

\begin{abstract}
Culture broth, cell pellet suspension and cell free supernatant of 14 Bacillus subtilis isolates obtained from different Egyptian locations were checked for their ability to repress egg hatching and juvenile (J2) activity of root-knot nematode, Meloidogyne incognita under laboratory environment. Treatments using culture broth of B. subtilis isolates B10 and B8, at a concentration of 50\%, recorded lowest percentages of hatched eggs reaching 44.7 and $46.3 \%$, respectively. Culture broth of B. subtilis isolate B10 at the same concentration showed a higher percentage of juvenile mortality reached $99.7 \%$. Batch fermentation was completed, using B. subtilis isolate B10 (Accession No. EF583055), which gave the lowest percentage of hatched eggs and the highest percentage of juvenile mortality of $M$. incognita, for maximizing biomass production and suppression effects of culture broth. Batch fermentation no. 2, which started in a bioreactor with optical density of 0.5 , was the best process that achieved a higher cell biomass and percentage of juvenile mortality of $4.52 \mathrm{~g} / \mathrm{l}$ and $74.3 \%$, respectively, using culture broth of $5 \%$. Under greenhouse conditions, culture broth, cell pellet suspension, and cell-free supernatant of B. subtilis isolate B10 were used to test their potential for reducing number of galls and egg masses in the roots of tomato plants. The treatment of using culture broth at a concentration $10 \mathrm{ml} /$ pot, $2 \times 10^{9} \mathrm{cfu} / \mathrm{ml}$ in a soil infested with M. incognita, was highly significant in decreasing number of galls and egg masses reaching the average of 9.3 and 6.7, with reduction percentage of 81.1 and $89.5 \%$, respectively, compared with the control treatment of $M$. incognita only. In addition, $B$. subtilis isolate B10 was formulated and applied as bionematicide to test its efficiency in reducing number of galls and egg masses. Treatment with bioformulation at a concentration of $0.1 \mathrm{~g} / \mathrm{pot}$ was more significant than the other concentrations in reducing number of galls and egg masses, reaching the average of 12 and 7 with a reduction percentage of 69.7 and $71.2 \%$, correspondingly.
\end{abstract}

Keywords: Bacillus subtilis, Meloidogyne incognita, Biocontrol, Fermentation, Bioformulation

\footnotetext{
* Correspondence: gaberam57@yahoo.com

Bioprocess Development Department, Genetic Engineering and

Biotechnology Research Institute, City of Scientific Research and

Technological Applications, Universities and Research Center, New Borg

El-Arab City, Alexandria, Egypt

Full list of author information is available at the end of the article
} 


\section{Background}

The root-knot nematodes, Meloidogyne spp., are one of the highly important soil-borne pathogens that cause great economic damages to horticultural and field crops, and considered one of the most dangerous plant-parasitic nematodes, which can infect approximately all of the world's main crop plants (Oka et al. 2000). Nematodes generally habitat the soil and usually attack the underground parts of plants; therefore, their management is a very complex (Stirling 1991). Different methods can be utilized for controlling Meloidogyne spp. such as cultural practices, resistant cultivars, and chemical nematicides which are easy for application and more effective. Concerns about public health and environmental safety are pushing for reducing chemical nematicides used in controlling of Meloidogyne spp. Thus, improvement of new alternative of management is needed, especially environmentally friendly methods. Management of Meloidogyne spp. can be achieved, using biocontrol agents (Siddiqui 2002 and Khan et al. 2008). Huang et al. (2016) reported that the highest ovicidal activity against $M$. incognita documented, using a combination of Syncephalastrum racemosum and Paecilomyces lilacinus at a concentration of $50 \%$, reduced $70 \%$ of egg hatching than the control. Moreover, the treatment with S. racemosum, at a concentration of $50 \%$, showed a best larvicidal activity, where the rate of mortality reached its highest value of 96.7\%. Bacillus spp. can produce lytic enzymes, cyclic lipopeptides (Gray et al. 2006), and many secondary metabolites that play an essential role in biocontrol of Meloidogyne spp. Many lytic enzymes are produced by $B$. cereus, including chitinase and glucanse (Csuzi 1978). These lytic enzymes have been demonstrated to be antagonistic to M. javanica (Wepuhkhulu et al. 2011). Cyclic lipopeptides of surfactin and iturin produced by B. subtilis were more able to inhibit egg hatching of $M$. incognita and play an imperative role in increasing the percentage of juvenile mortality (Kavitha et al. 2012). The main goal of fermentation process is scaling-up production of cell biomass and the biological products. Matar et al. (2009) maximized cell biomass of B. subtilis isolate G-GANA7, as a bioagent against some plant pathogens, using batch fermentation strategy that achieved a cell biomass of $3.2 \mathrm{~g} / \mathrm{l}$. Scaling-up production of surfactin (lipopeptide) from $B$. subtilis to be used as a bioagent was performed in an innovative bioreactor, maximum concentration of surfactin achievement was $6.45 \mathrm{~g} / \mathrm{l}$ (Yeh et al. 2006). Population densities and galls of root-knot nematodes, Meloidogyne spp. decreased by using the treatments with Pseudomonas aeruginosa, B. subtilis, and antagonistic fungus P. lilacinus (Prakob et al. 2009). Also, B. cereus X5 was effective in suppression of root-knot nematodes, hence number of galls of tomato roots decreased compared to the control (Tong-Jian et al. 2012). Burkett-Cadena et al. (2008) reported that formulations (contained strains of bacilli) of Equity $^{\odot}$ (multiple strains), BioYield ${ }^{\odot}$ (two strains), and RhizoVital $^{\oplus}$ (strain FZB42) reduced $M$. incognita eggs per gram root, juvenile nematodes per gram of soil, and galls per plant on tomato.

The main objective of this study was to evaluate the antagonistic and suppression effects of culture broth, cell pellet suspension, and cell free supernatant of $B$. subtilis isolates on egg hatching and juvenile (J2) activity of $M$. incognita under laboratory conditions. In addition, to maximize both biomass production and suppression effects of the promising $B$. subtilis isolate, using batch fermentation. As well, to evaluate their efficacy to reduce number of galls and egg masses in the roots of tomato plants under greenhouse conditions.

\section{Materials and methods}

Bacterial isolates and root-knot nematode, $M$. incognita

Fourteen B. subtilis isolates were isolated during 200203 from 5 locations in Egypt (El-Malaha, El-Amria, El-Nobaria, Abo-Homos, and El-Sharkia) by Dr. Abo-Zaid, G.A., Bioprocess Development Department, Genetic Engineering and Biotechnology Research Institute (GEBRI), City of Scientific Research and Technological Applications (SRTA-City), Egypt. All the isolates were identified according to the morphological, biochemical, and physiological tests recommended by Sneath et al. (1986) and Collee et al. (1996). Seven B. subtilis isolates; B1, B4, B7, B8, B10, B11, and B14 were identified based on the sequencings of $16 \mathrm{~S}$ rRNA gene. The root-knot nematode, $M$. incognita used in this study was provided by Plant Pathology Department, Faculty of Agriculture, Alexandria University, Egypt.

\section{Cultivation in shake-flask}

Growth of the 14 B. subtilis cultures was conducted in shake flasks under constant controlled conditions of temperature, $\mathrm{pH}$, and agitation. Bacterial colonies of $B$. subtilis isolates were inoculated into a nutrient liquid medium (peptone, $5 \mathrm{~g} / \mathrm{l}$ and beef extract, $3 \mathrm{~g} / \mathrm{l}$ ) and incubated overnight $(16 \mathrm{~h})$ at $30{ }^{\circ} \mathrm{C}$, with a constant shaking at $200 \mathrm{rpm} .1 \mathrm{ml}$ of each culture was transferred into a $250 \mathrm{ml}$ Erlenmeyer flask containing $49 \mathrm{ml}$ of number 3 medium of which each $1 \mathrm{~L}$ contained $10 \mathrm{~g}$ peptone, $10 \mathrm{~g}$ glucose, $1 \mathrm{~g} \mathrm{KH}_{2} \mathrm{PO}_{4}$ and $0.5 \mathrm{~g} \mathrm{MgSO}_{4}$. $7 \mathrm{H}_{2} \mathrm{O}$ in distilled water and $\mathrm{pH}$ was adjusted to 7 (Asaka and Shoda 1996). Cultures were incubated overnight at $30{ }^{\circ} \mathrm{C}$ and shacked at $200 \mathrm{rpm}$ until reaching $2 \times 10^{9} \mathrm{cfu} / \mathrm{ml} .20 \mathrm{ml}$ of each culture was centrifuged at $5590 \times \mathrm{g}$ for $20 \mathrm{~min}$, and its cell free supernatant was collected and passed through a syringe filter $(0.2 \mu)$. Also, cell pellet of each isolate was collected, washed, and centrifuged at $5590 \times g$ for $20 \mathrm{~min}$. Cell pellet of each culture was suspended in 
$20 \mathrm{ml}$ of sterile distilled water. The culture broth, cell-free supernatant, and cell pellet of these bacterial isolates were used for treatments in dilutions of their original concentrations, namely, 1:1 (50\%), 1:4 (25\%), and $1: 10(10 \%)$.

\section{In vitro suppressive effect of $B$. subtilis isolates against $M$.} incognita

Culture broth, cell pellet suspension, and cell-free supernatant of each $B$. subtilis isolate were examined for its ability to inhibit egg hatching and juvenile (J2) activity. Approximately 50 eggs and 50 juveniles (J2) were transferred into each well of a 12-well plate. Afterwards, culture broth, cell pellet suspension, and cell-free supernatant of the $14 \mathrm{~B}$. subtilis isolates were added separately at a concentration of $50 \%$. Culture broth, cell pellet suspension and cell-free supernatant of the five $B$. subtilis isolates; B4, B5, B7, B8 and B10 were added at the concentrations of 25 and $10 \%$. The control treatment included medium free from $B$. subtilis isolates. The plates were covered and incubated at $25^{\circ} \mathrm{C}$ for $72 \mathrm{~h}$. Three replicates/treatment were analyzed. The percentages of hatched eggs and survival of juveniles were counted under microscope (Huang et al. 2016).

\section{Fermentation experiment} Bioreactor (fermentor)

Batch fermentation was performed, according to Matar et al. (2009), in a working volume of $4 \mathrm{~L}$ in a $10 \mathrm{~L}$ bench-top bioreactor (Cleaver, Saratoga, USA), prepared with three 6-bladed disc-turbine impeller and four baffles, and joined to a digital control unit. The process was automated through a control unit provided with control panel of 10.4 color touch-screen interface and storage program up to 59,994 programs for different kinds of conditions. Temperature and $\mathrm{pH}$ were adjusted at $30{ }^{\circ} \mathrm{C}$ and 7 , correspondingly. $\mathrm{pH}$ was controlled by automatic feed of $2 \mathrm{~N} \mathrm{NaOH}$ and $2 \mathrm{~N} \mathrm{HCl}$. Sterilized air passed through sterile filter was supplied, originally at $0.5 \mathrm{VVM}$ (air volume per medium volume per minute). Agitation rate ranged between 200 and $400 \mathrm{rpm}$ to maintain the dissolved oxygen level above 20\%. METTLER TOLEDO electrodes were used to determine the dissolved oxygen level and $\mathrm{pH}$ values on-line.

\section{Batch fermentation}

Two batch fermentation runs of B. subtilis isolate B10 (Accession No. EF583055), which gave the lowest percentage of hatched eggs and the highest percentage of juvenile mortality of $M$. incognita, were started in a

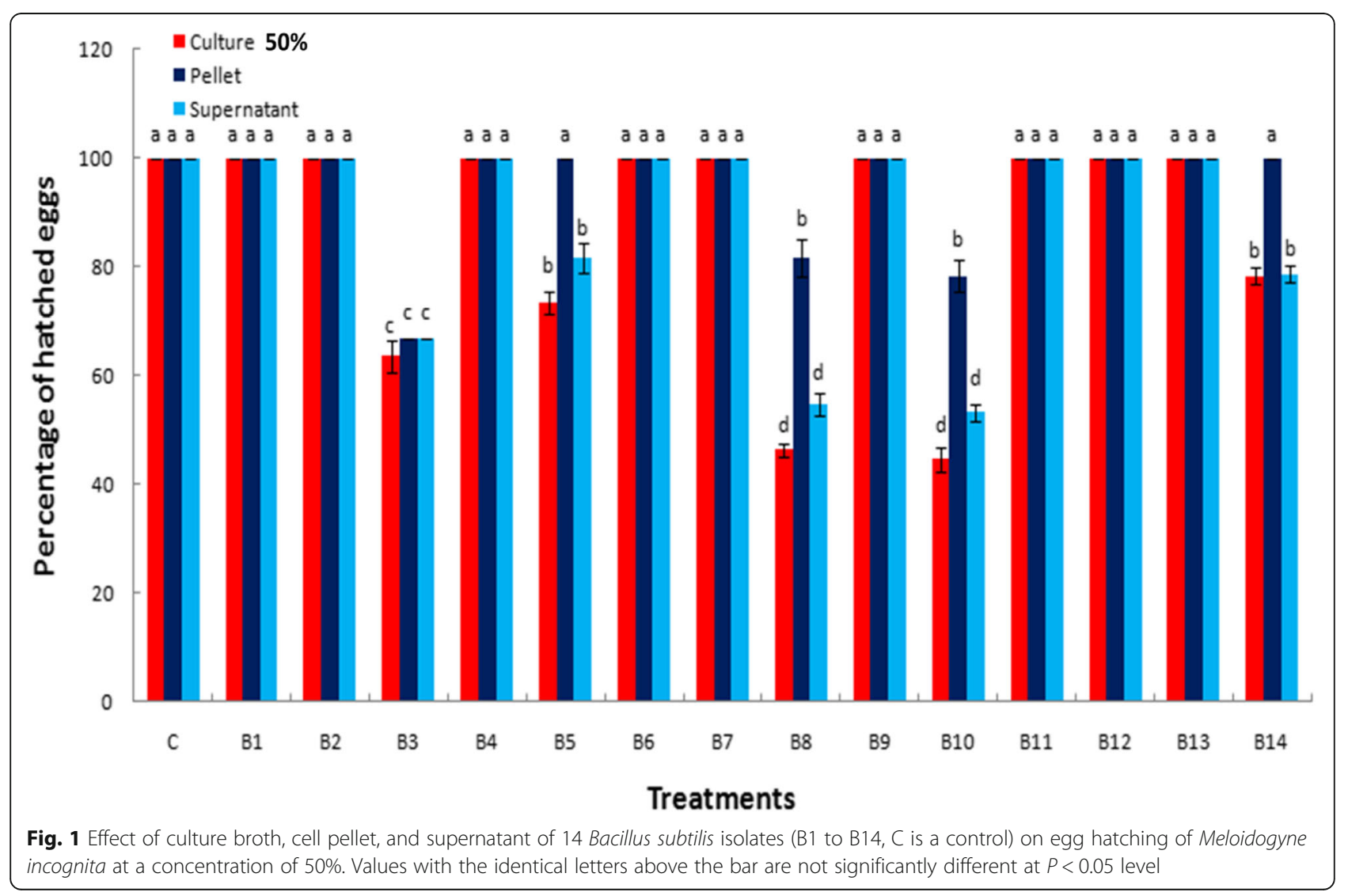


fermentor, with an optical density of 0.2 and 0.5 at $550 \mathrm{~nm}$, using number 3 medium (Asaka and Shoda 1996). Shake flask pre-cultured seed was prepared as follows: a single colony of $B$. subtilis isolate B10 was inoculated into a $500 \mathrm{ml}$ Erlenmeyer flask containing
$100 \mathrm{ml}$ of production medium of N3 medium. Bacterial isolate was cultured overnight at $30{ }^{\circ} \mathrm{C}$ and shacked at $200 \mathrm{rpm}$. During the time of the two batch fermentation, several samples of culture were taken and cell number was determined by measuring culture optical
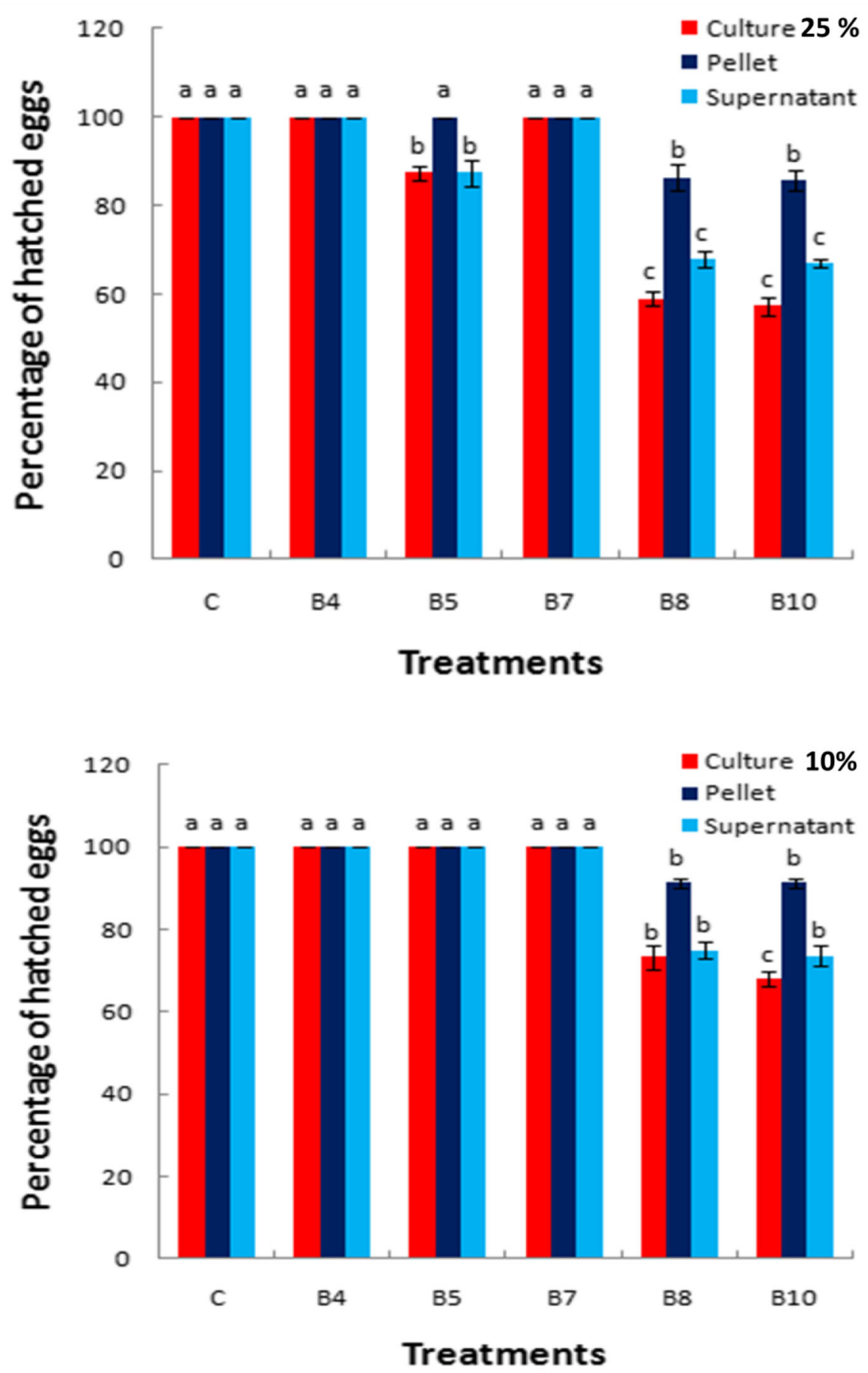

Fig. 2 Effect of culture broth, cell pellet, and supernatant of five Bacillus subtilis isolates (B4, B5, B7, B8, and B10, C is a control) on egg hatching of Meloidogyne incognita at a concentration of $25 \%$ and $10 \%$. Values with the identical letters above the bar are not significantly different at $P<0.05$ level 
density at $550 \mathrm{~nm}$. Glucose level was estimated enzymatically (Matar et al. 2009), using (GOD-PAD) colorimetric kit (Diamond Diagnostic, Egypt). Ability of culture broth of $B$. subtilis isolate B10 to antagonize and inhibit juvenile (J2) activity of $M$. incognita at a concentration of 5\% (1:20) was tested (Huang et al. 2016). Dry cell weight was estimated by centrifuging $10 \mathrm{ml}$ sample at $894 \times g$ for $10 \mathrm{~min}$, and the pellet was re-suspended, washed, and centrifuged again as before. Pellets were then dried overnight in a dry-air oven at $80{ }^{\circ} \mathrm{C}$ (Van Dam-Mieras et al. 1992).

\section{Suppressive effect of $B$. subtilis isolate B10 against $M$. incognita under greenhouse conditions}

A pot experiment was carried out under greenhouse conditions, using tomato plants as a host plant. Twenty four pots $(25 \times 25 \mathrm{~cm}$ in diameter $)$ were filled by $5 \mathrm{~kg}$ mixture of sterilized clay and sand $(2: 1 \mathrm{v} / \mathrm{v})$, and the nematode eggs were applied at the rate of 1000 eggs/pot, 3 days after transferring tomato seedlings (30 days old) to the pots. Culture broth, cell pellet suspension, and cell-free supernatant of $B$. subtilis isolate B10 were applied at a concentration $\left(10 \mathrm{ml} /\right.$ pot, $\left.2 \times 10^{9} \mathrm{cfu} / \mathrm{ml}\right)$ twice, 3 days after nematode inoculation and 1 month after the first treatment as a soil drench. Each treatment was accomplished by three replicates. Eight treatments were performed as follows: (1) M. incognita as a check treatment; (2) untreated control; (3) culture broth; (4) cell pellet suspension (5) cell-free supernatant; (6) $M$. incognita + culture broth; (7) M. incognita + cell pellet suspension; and (8) M. incognita + cell-free supernatant. The plants were up-rooted after 60 days then root galls and egg masses were determined. Also, the fresh and dry weight of shoots and roots were determined. The roots were stained for $15 \mathrm{~min}$ in an aqueous solution of Phloxine B stain $(0.15 \mathrm{~g} / \mathrm{l}$ water), then washed with running tap water to remove residual stain and detect the presence of nematode egg masses (Holbrook et al. 1983).

\section{Formulation experiment and preparation of $B$. subtilis isolate B10}

Talc powder (TP) was used for preparing a bioformulation. The culture broth containing $2.0 \times 10^{9} \mathrm{cfu} / \mathrm{m} 1$ of $B$. subtilis isolate $\mathrm{B} 10$ was used for the preparation. To $400 \mathrm{ml}$ of culture broth, $2 \mathrm{~g}$ of glucose and $10 \mathrm{~g}$ of carboxymethylcellulose (CMC) were added as additives. Glucose served as carbon source for keeping the cells

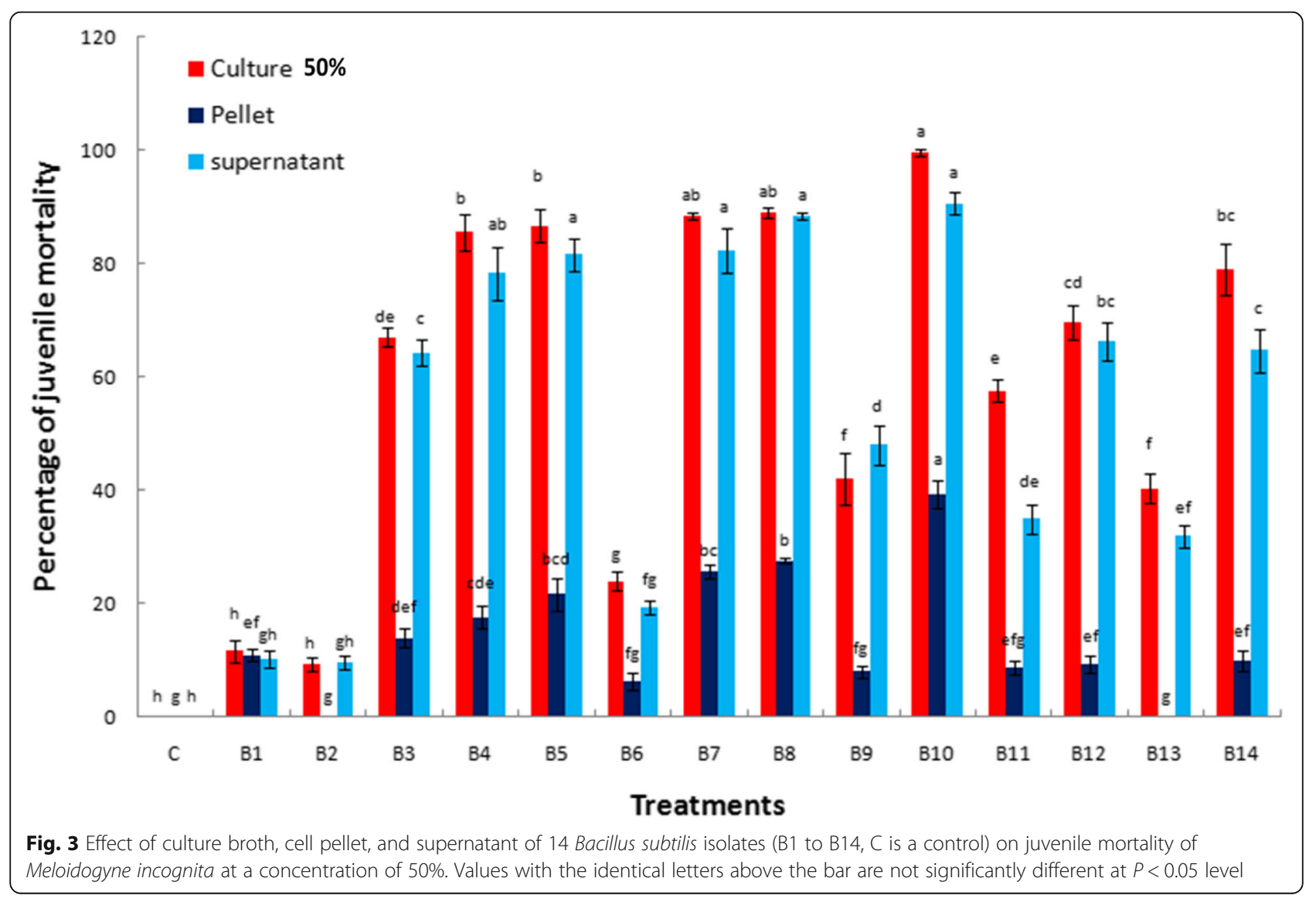



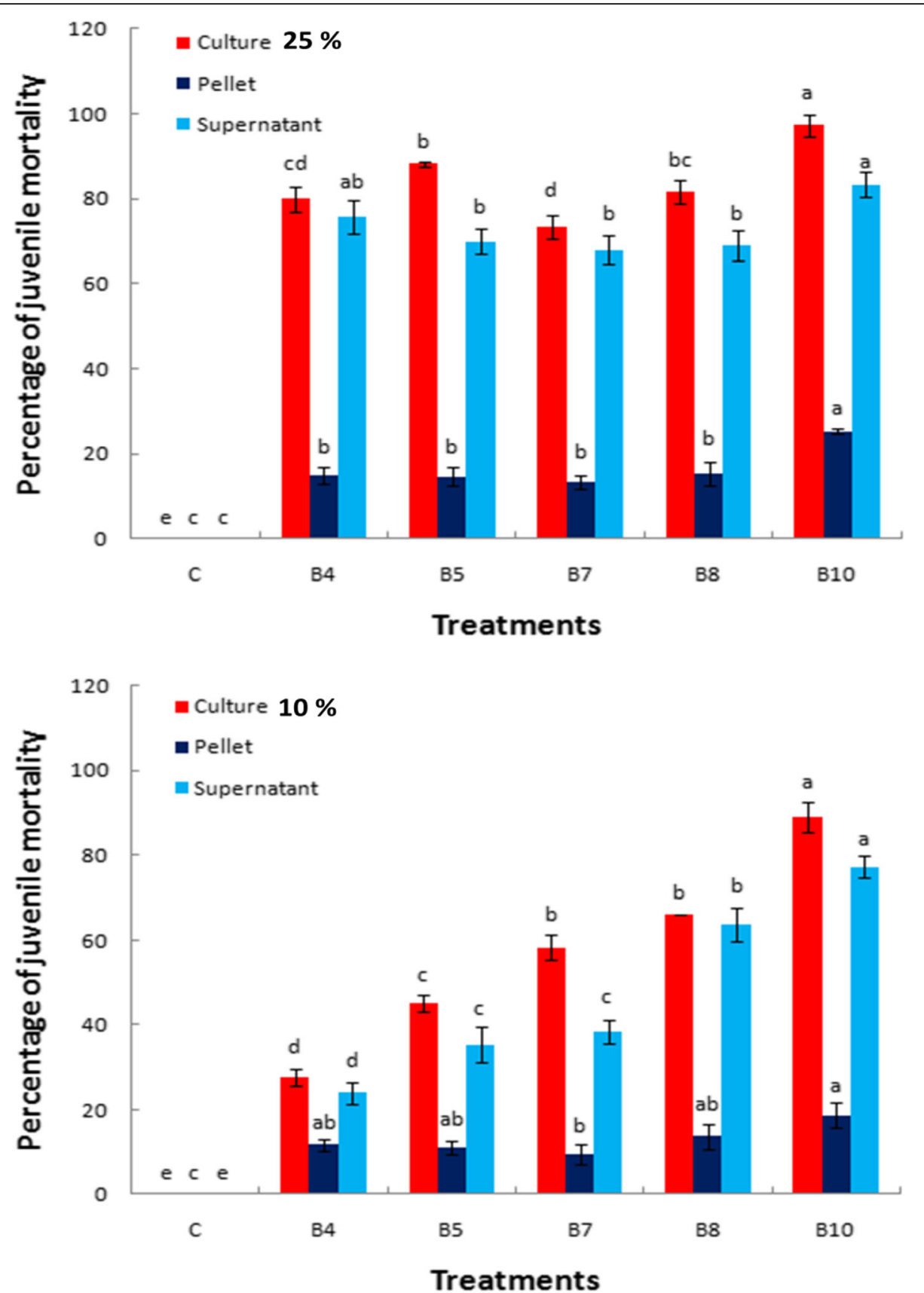

Fig. 4 Effect of culture broth, cell pellet, and supernatant of five Bacillus subtilis isolate (B4, B5, B7, B8, and B10, C is a control) on juvenile mortality of Meloidogyne incognita at a concentration of $25 \%$ and $10 \%$. Values with the identical letters above the bar are not significantly different at $P<0.05$ level

viable, while CMC acted as an adhesive. The culture broth and additives were mixed uniformly on a vortex mixer. $15 \mathrm{~g}$ of calcium carbonate was added to $1 \mathrm{~kg}$ of talc powder (TP) and mixed well for adjusting the $\mathrm{pH}$ to 7.0. Four hundreds $\mathrm{ml}$ of culture broth with additives were mixed with $1 \mathrm{~kg}$ of the talc powder. The formulation was shade-dried to reduce the moisture content to $\sim 20 \%$ and then packed in UV-sterilized polythene bags and sealed (Vidhyasekaran and Muthamilan 1995).
Effect of formulated B. subtilis isolate B10 on $M$. incognita under greenhouse conditions

A pot experiment was carried out under greenhouse conditions, using tomato plants as a host plant. Twenty seven pots $(15 \times 15 \mathrm{~cm}$ in diameter $)$ were filled by $3 \mathrm{~kg}$ mixture of clay and sand $(2: 1 v / v)$, and the nematode eggs were applied at the rate of 1000 eggs/pot, 3 days after transferring tomato seedlings (30 days old) to pots. Formulation contained B. subtilis isolate B10 was applied 


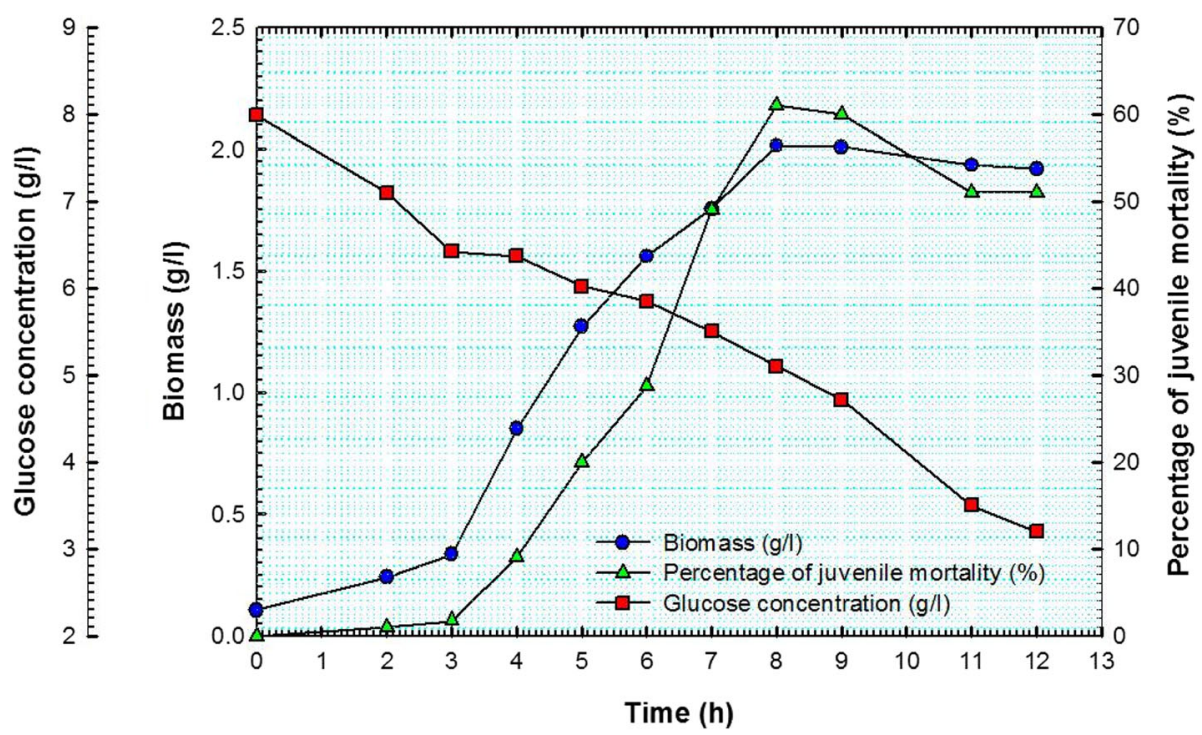

Fig. 5 Biomass, percentage of juvenile mortality at a concentration of $5 \%$ and glucose concentration as a function of time for batch fermentation no. 1 of Bacillus subtilis isolate B10

at a concentration of $0.02,0.06$, and $0.1 \mathrm{~g} /$ pot twice, 3 days after nematode inoculation and 1 month after the first treatment, as a soil drench. Each treatment was accomplished by three replicates. Nine treatments were performed as follows: (1) M. incognita as a check treatment; (2) untreated control; (3) formulation $0.02 \mathrm{~g} / \mathrm{pot}$; (4) formulation $0.06 \mathrm{~g} /$ pot (5) formulation $0.1 \mathrm{~g} /$ pot; (6) M. incognita + formulation $0.02 \mathrm{~g} / \mathrm{pot}$; (7) M. incognita + formulation $0.06 \mathrm{~g} / \mathrm{pot}$; (8) M. incognita + formulation

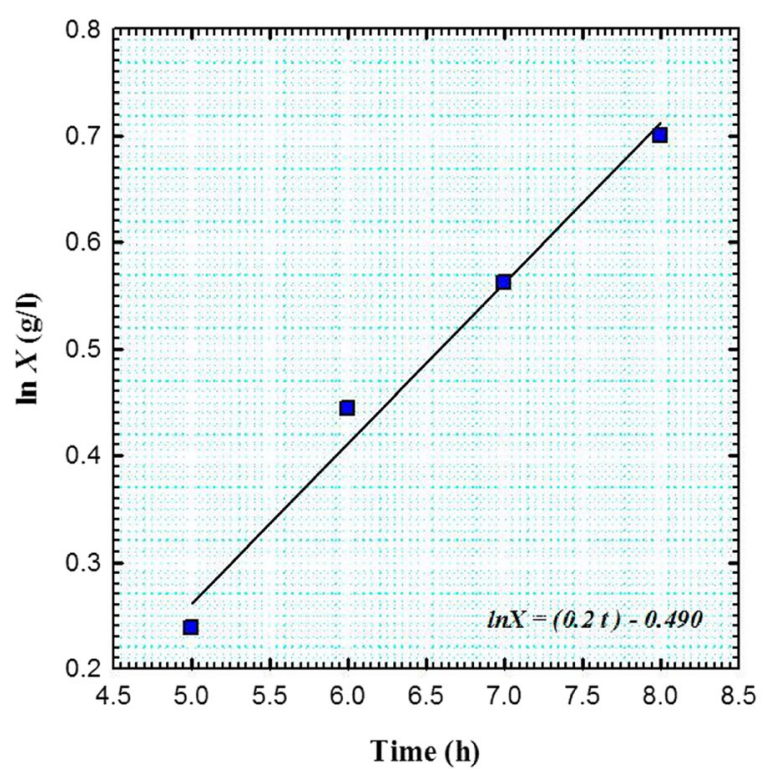

Fig. $6 \mathrm{Ln}$ biomass $(X)$ in $\mathrm{g} / \mathrm{l}$ as a function of time in the exponential growth phase of batch fermentation no. 1 of Bacillus subtilis isolate B10
$0.1 \mathrm{~g} /$ pot; and (9) M. incognita + Vydete $(2 \mathrm{ml} / \mathrm{l})$. The plants were up-rooted after 50 days, and then root galls and egg masses were determined. The fresh and dry weight of shoots and roots were determined as mentioned before (Holbrook et al. 1983).

\section{Statistical analysis}

All data obtained from laboratory bioassay and pots experiments were analyzed using analysis of variance (ANOVA). The significant differences among treatments were determined according to the least significant differences (LSD) at $P<0.05$ level of probability, using the CoStat software.

\section{Results and discussion}

Culture broth, cell pellet suspension, and cell-free supernatant of all $B$. subtilis isolates were tested for their ability to suppress both egg hatching and juvenile (J2) activity at a concentration of $50 \%$. Five $B$. subtilis isolates, B4, B5, B7, B8, and B10, were also tested at different concentration of 25 and $10 \%$. Not all B. subtilis isolates were capable to inhibit egg hatching of $M$. incognita at a concentration of 50\%, except B3, B5, B8, B10, and B14. Culture broth and supernatant of B. subtilis isolates B10 and B8 had a maximum activity against egg hatching of $M$. incognita; hence, the percentages of hatched eggs were 44.7 and $46.3 \%$, using a culture broth, while it reached 53.3 and $54.7 \%$, respectively, by using the supernatant. Cell pellet suspension of B. subtilis isolate B3 recorded the lowest percentage of hatched eggs, reaching $67 \%$ compared with the treatments with cell pellet suspension of $B$. subtilis isolates $\mathrm{B} 10$ and $\mathrm{B} 8$, 


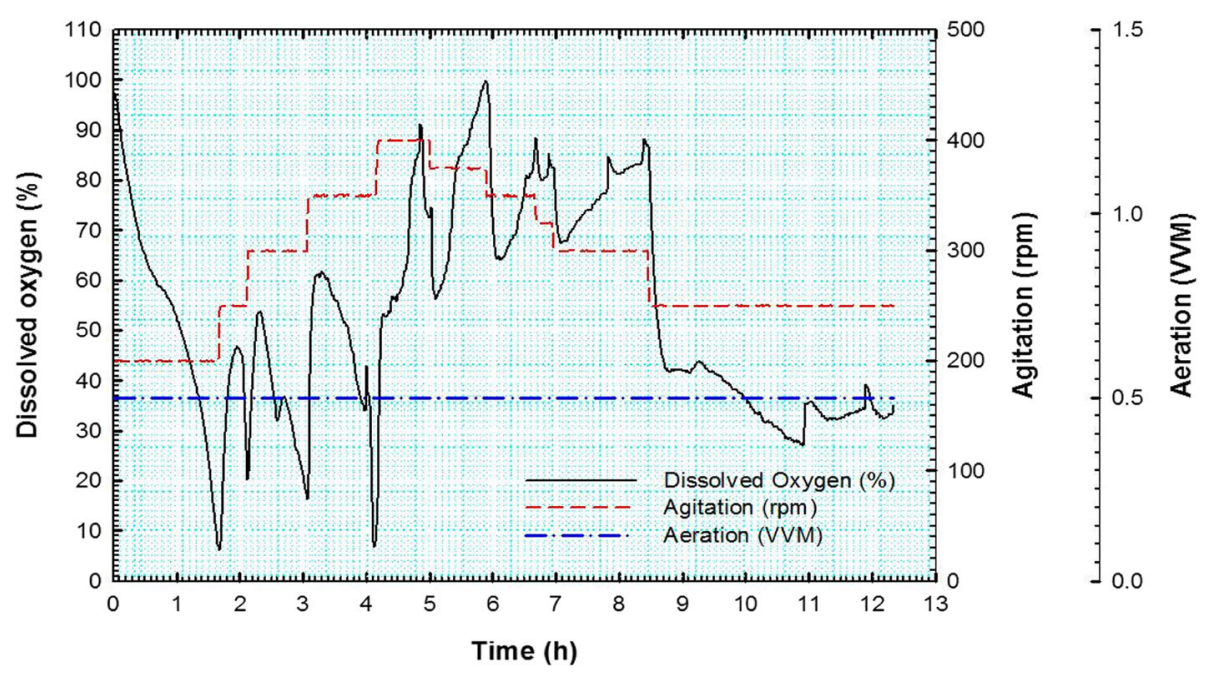

Fig. 7 Dissolved oxygen, agitation, and aeration as a function of time during batch fermentation no. 1 of Bacillus subtilis isolate B10

where the percentage of hatched eggs recorded 78.3 and $81.7 \%$, respectively (Fig. 1). At a concentration of $25 \%$, culture broth and supernatant of B. subtilis isolates B10 and B8 inhibited egg hatching of $M$. incognita with percentages of hatched eggs of 57.3 and $59 \%$, using culture broth, respectively, while the percentages of hatched eggs were 67 and $68 \%$ by using supernatant, respectively. Cell pellet suspension of B. subtilis isolate B10 and B8 recorded approximately 85.7 and $86.3 \%$, respectively, of hatched eggs (Fig. 2). Capability of B. subtilis isolates to suppress egg hatching at a concentration of $10 \%$ was lowest, the percentages of hatched eggs in the treatment, using the culture broth and supernatant of B. subtilis isolate B10, were 68 and $73.7 \%$, respectively, while the treatment, using cell pellet suspension recorded approximately 91.3\% egg hatching (Fig. 2). Culture broth and cell-free supernatant of all $B$. subtilis isolates had antagonistic effect against juvenile (J2) activity of $M$. incognita compared with those at the highest concentration of $50 \%$, whereas cell pellet suspension of B. subtilis isolates B2 and B13 did not show any suppression effects. Culture broth of $B$. subtilis isolate B10 showed highly percentage of juvenile mortality, followed by B8 and B7, which reached 99.7, 89, and 88.3\%, respectively. Furthermore, the treatments of using supernatant of B. subtilis isolate B10, B8, and B7 showed 90.7, 88.3, and 82.3\% mortality, respectively. In the treatment of using cell pellet suspension, the percentage of juvenile mortality did

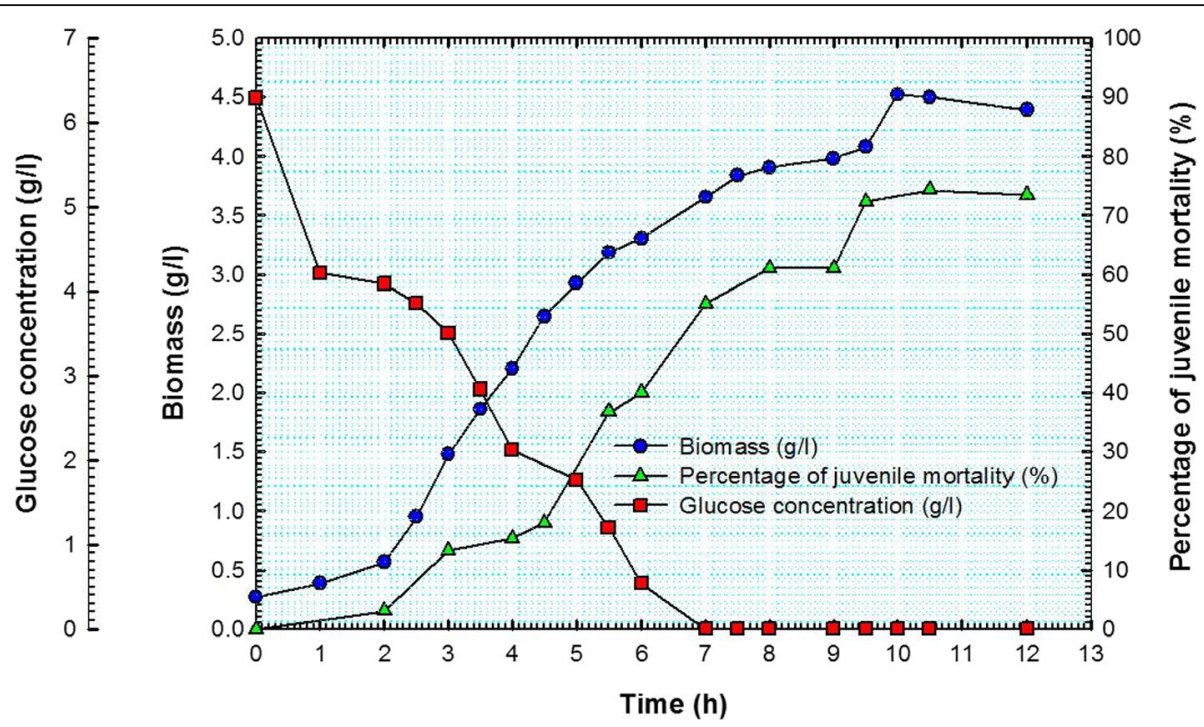

Fig. 8 Biomass, percentage of juvenile mortality at a concentration of 5\%, and glucose concentration as a function of time for batch fermentation no. 2 of Bacillus subtilis isolate B10 


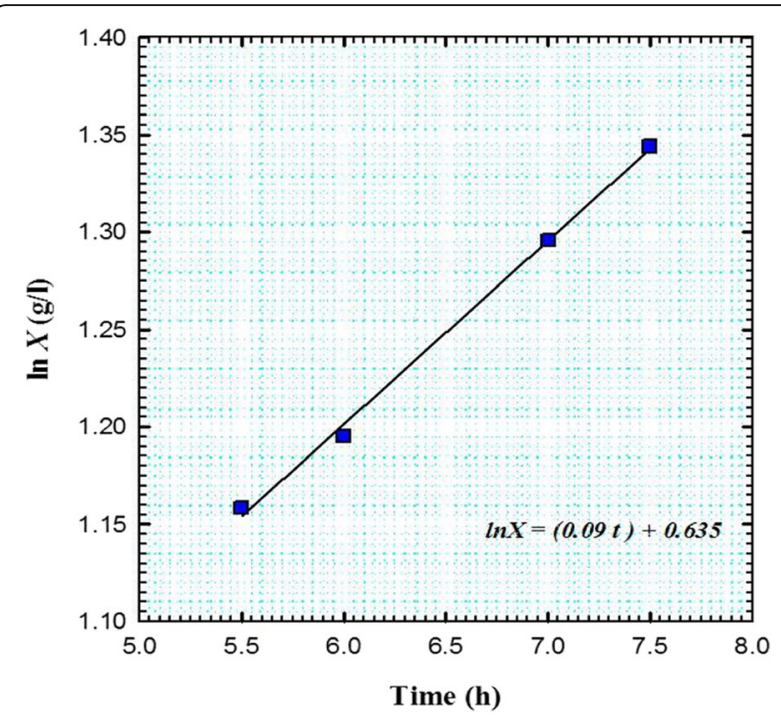

Fig. 9 Ln biomass $(X)$ in $g / l$ as a function of time in the exponential growth phase of batch fermentation no. 2 of Bacillus subtilis isolate B10

not exceed $39.3 \%$ with B. subtilis isolate B10 (Fig. 3). Treatment with culture broth and supernatant of B. subtilis isolate B10, at concentrations of 25 and $10 \%$, achieved the highest percentages of juvenile mortality ( 97.3 and $89 \%$ ) by using culture broth, respectively, while it reached 83.3 and $77.3 \%$ by using supernatant, respectively. The percentages of juvenile mortality were the lowest in the treatment using cell pellet suspension at concentrations of 25 and 10\%. Cell pellet suspension of

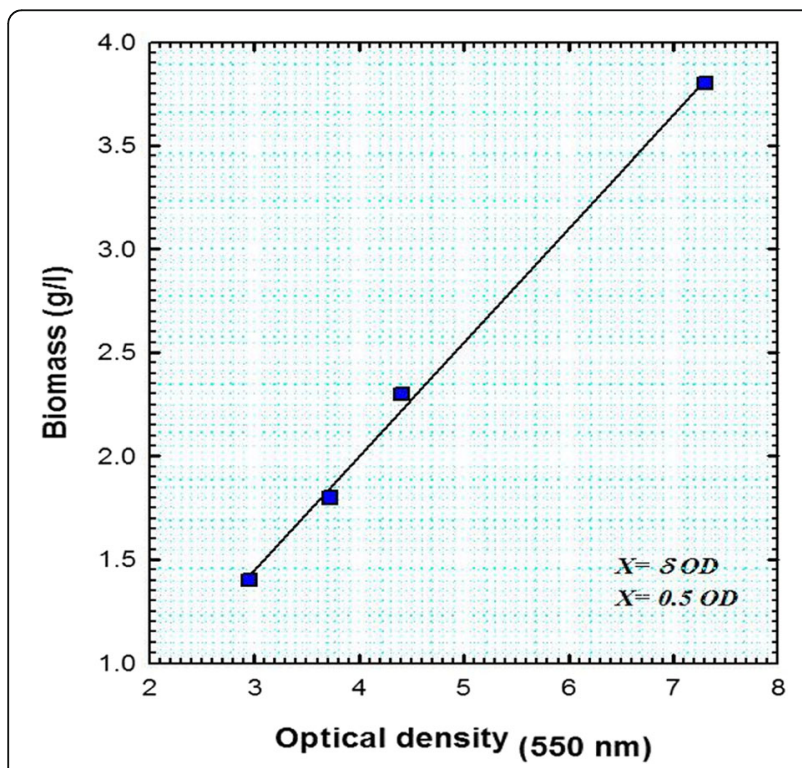

Fig. 10 The correlation between optical density $\left(\mathrm{OD}_{550 \mathrm{~nm}}\right)$ and biomass $(\mathrm{g} / \mathrm{l})$ in the exponential growth phase of batch fermentation no. 2 of Bacillus subtilis isolate B10

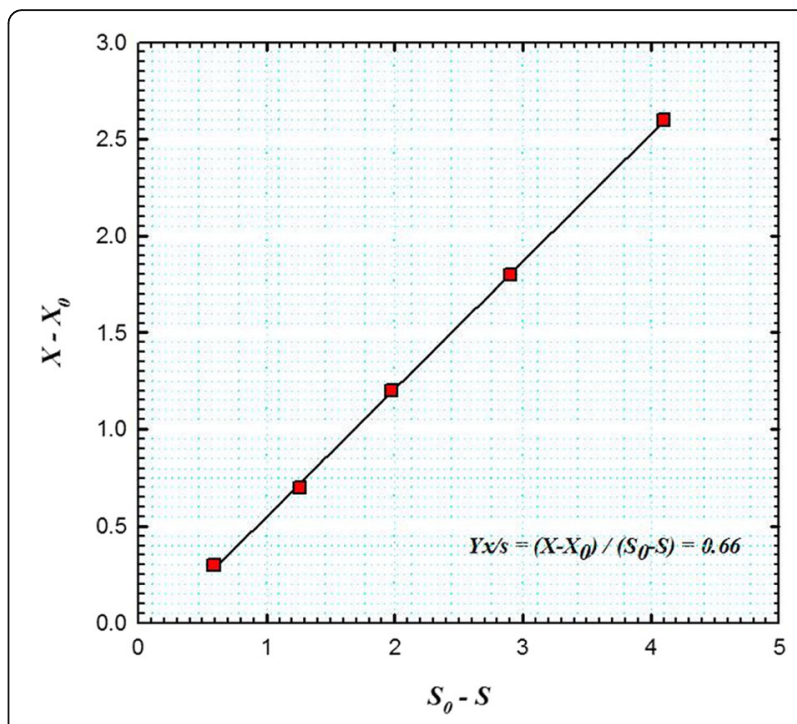

Fig. 11 Yield coefficient for growth of Bacillus subtilis isolate B10 on glucose. $X_{0}$ represents the cell mass in the broth at initial time $t_{0}(\mathrm{~g} /$ I); $X$, the cell mass concentration in the broth at time $t(\mathrm{~g} / \mathrm{l})$; $S$, glucose concentration in the broth at time $\mathrm{t}(\mathrm{g} / \mathrm{l})$; $S_{0}$, glucose concentration in the broth at initial time $t_{0}(\mathrm{~g} / \mathrm{l})$

B. subtilis isolate B10 recorded highest percentages of juvenile mortality that reached 25.3 and $18.7 \%$, respectively, compared with the other isolates (Fig. 4). Nematicidal activity of culture broth and cell-free supernatant of B. subtilis isolates, used in this study as biocontrol agents, may be referred to the ability of these isolates to produce lytic enzymes such as chitinase, glucanase, and protease that affect nematode cuticles and eggs (Page et al. 2014 and Chen et al. 2015) and cyclic lipopeptides such as iturin and surfactin, that may influence nematode behavior (Castaneda-Alvarez and Aballay 2016). The treatment of using B. cereus achieved a lower egg hatching rate and a higher mortality of $\mathrm{J} 2$ of root-knot nematodes, Meloidogyne spp. than the control, which related to extracellular proteins or substances produced in filtrate (Xiao et al. 2012 and Huang et al. 2016). Also, Kavitha et al. (2012) suggested that cyclic lipopeptides of surfactin and iturin produced by B. subtilis were responsible for suppression egg hatching of $M$. incognita and increasing the percentage of juvenile mortality.

Batch fermentation of $B$. subtilis isolate B10, which gave the lowest percentage of hatched eggs and the highest percentage of juvenile mortality of $M$. incognita, was carried out in a $10 \mathrm{~L}$ bench-top bioreactor (Cleaver, Saratoga, USA) to achieve maximum biomass production and suppressive effect using culture broth. In batch fermentation no. 1 that started in a bioreactor with an optical density of 0.2 (inoculums size) at $550 \mathrm{~nm}$, the maximum biomass obtained was $2.015 \mathrm{~g} / \mathrm{l}$ at $8 \mathrm{~h}$. Glucose concentration was decreased gradually reaching $3.2 \mathrm{~g} / \mathrm{l}$ at $12 \mathrm{~h}$. Percentage of juvenile mortality of $M$. 

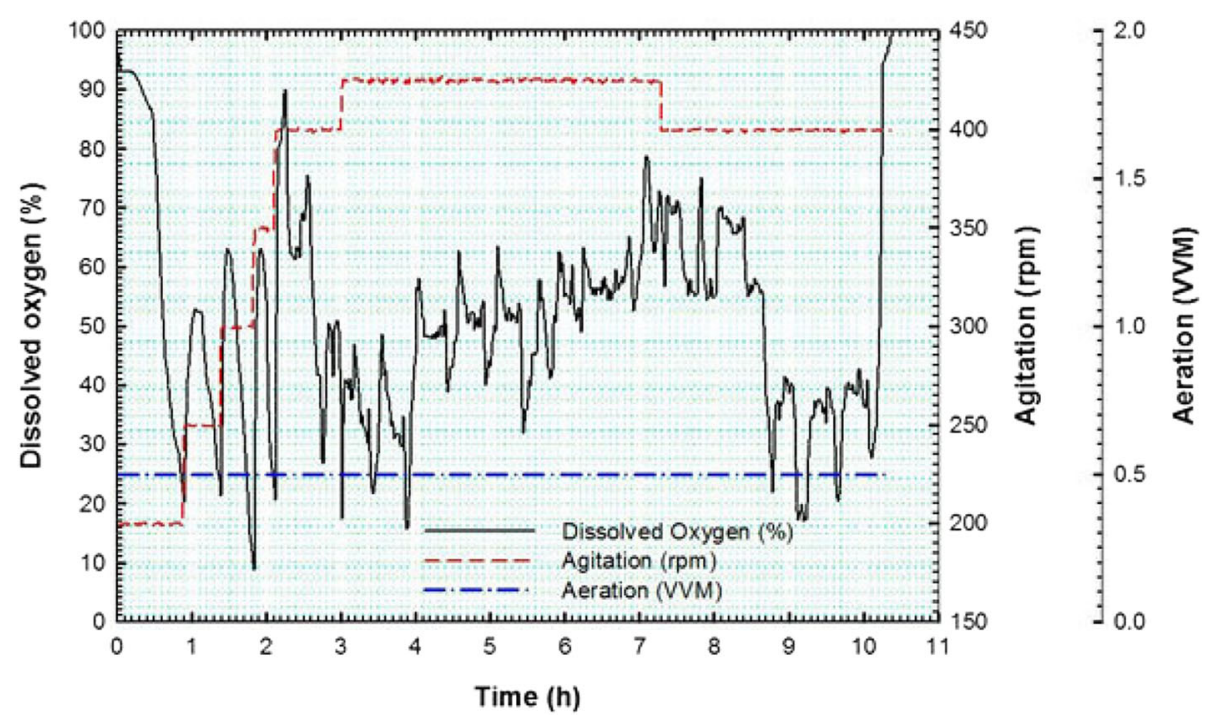

Fig. 12 Dissolved oxygen, agitation, and aeration as a function of time during batch fermentation no. 2 of Bacillus subtilis isolate B10

incognita [at a concentration of $5 \%(1: 20)]$ at $2 \mathrm{~h}$ recorded $1 \%$ and reached its highest value of $61 \%$ at $8 \mathrm{~h}$ (Fig. 5). The culture grew exponentially with a specific growth rate of $0.2 \mathrm{~h}^{-1}$ (Fig. 6). The culture was maintained at a higher value of dissolved oxygen which reduced step by step after $1.5 \mathrm{~h}$, representing bacterial cells growth and glucose consumption from the culture broth. The dissolved oxygen reduced as a result of the rising in $\mathrm{O}_{2}$ require for growing the culture (Fig. 7). To assure a sufficient oxygen supply, oxygen was reserved at above $(20 \%)$ by raising the agitation speed. In batch fermentation no. 2 that started in a bioreactor with optical density of 0.5 at $550 \mathrm{~nm}$, biomass, percentage of juvenile mortality of $M$. incognita and glucose concentration of $B$. subtilis isolate B10 plotted against time, the maximum biomass achieved was $4.52 \mathrm{~g} / \mathrm{l}$ at
$10 \mathrm{~h}$ (Fig. 8). Percentage of juvenile mortality of $M$. incognita [at a concentration of $5 \%(1: 20)$ ] at $2 \mathrm{~h}$ recorded $13.3 \%$ and reached its highest value of $74.3 \%$ at $10.5 \mathrm{~h}$. Glucose concentration decreased rapidly reaching $0 \mathrm{~g} / \mathrm{l}$ at $7 \mathrm{~h}$. Cell mass increased exponentially over time with a constant specific growth rate of $0.09 \mathrm{~h}^{-1}$ within the exponential phase, resulted from the logarithmic relationship (Fig. 9). In this figure, the values of the $\ln X$ (values of $X$ were obtained by using the correlation coefficient $\delta$, 0.5 calculated from the linear relationship among dry mass weight and optical density shown in Fig. 10) were presented by a straight line on a semi-logarithm plot against time. The behavior in this phase allowed estimating the yield coefficient $Y_{X / S}(0.66 \mathrm{~g}$ cells/g glucose) as showed in Fig. 11. Culture was maintained at a higher value of dissolved oxygen, which decreased gradually

Table 1 Effect of culture broth, cell pellet, and supernatant of Bacillus subtilis isolate B10 on number of galls and egg masses of Meloidogyne incognita occurrence in the roots of tomato plants

\begin{tabular}{lllll}
\hline Treatment $^{\mathrm{X}}$ & Number of galls & Reduction $^{Y} \%$ & Egg masses & Reduction $^{Y} \%$ \\
\hline $\mathrm{N}$ & $49.3 \pm 3.1^{1^{\mathrm{a}}}$ & 0 & $64 \pm 2.6^{\mathrm{a}}$ & 0 \\
$\mathrm{C}$ & $0 \pm 0^{\mathrm{e}}$ & - & $0 \pm{ }^{\mathrm{e}}$ & - \\
$\mathrm{CU}$ & $0 \pm 0^{\mathrm{e}}$ & - & $0 \pm{ }^{\mathrm{e}}$ & - \\
$\mathrm{P}$ & $0 \pm 0^{\mathrm{e}}$ & - & $0 \pm{ }^{\mathrm{e}}$ & - \\
$\mathrm{S}$ & $0 \pm 0^{\mathrm{e}}$ & - & $0 \pm{ }^{\mathrm{e}}$ & - \\
$\mathrm{N}+\mathrm{CU}$ & $9.3 \pm 1.5^{\mathrm{d}}$ & 81.1 & $6.7 \pm 1.2^{\mathrm{d}}$ & 89.5 \\
$\mathrm{~N}+\mathrm{P}$ & $18 \pm 2^{\mathrm{c}}$ & 63.5 & $10 \pm 1.7^{\mathrm{C}}$ & 84.4 \\
$\mathrm{~N}+\mathrm{S}$ & $27 \pm 2.6^{\mathrm{b}}$ & 45.2 & $21 \pm 2.6^{\mathrm{b}}$ & 67.2 \\
$\mathrm{LSD}$ & 4.7 & & 2.6 & \\
\hline
\end{tabular}

${ }^{x_{N}, M}$. incognita; $C$, untreated control; $C U$, culture broth; $P$, cell pellet; $S$, supernatant; $N+C U, M$. incognita + culture broth; $N+P, M$. incognita + cell pellet; $N+S$, $M$. incognita + supernatant

${ }^{Y}$ Reduction \% $=$ [check-treatment $] /$ check $\times 100$

*Means in each column followed by the identical letter do not differ significantly at $P<0.05$ level 
Table 2 Effect of culture broth, cell pellet, and supernatant of Bacillus subtilis isolate B10 on fresh and dry weight of shoots and roots of tomato plants

\begin{tabular}{|c|c|c|c|c|c|c|c|c|}
\hline Treatment $^{x}$ & $\begin{array}{l}\text { Fresh weight of } \\
\text { Shoots }(\mathrm{g})\end{array}$ & Increase ${ }^{z}(\%)$ & $\begin{array}{l}\text { Dry weight } \\
\text { of shoots }(\mathrm{g})\end{array}$ & Increase ${ }^{z}(\%)$ & $\begin{array}{l}\text { Fresh weight } \\
\text { of roots }(\mathrm{g})\end{array}$ & Increase ${ }^{z}(\%)$ & $\begin{array}{l}\text { Dry weight } \\
\text { of roots }(\mathrm{g})\end{array}$ & Increase $^{z}(\%)$ \\
\hline N & $26.4 \pm 1.9^{f *}$ & - & $6.1 \pm 0.8^{e}$ & - & $14.3 \pm 0.4^{\mathrm{e}}$ & - & $6.4 \pm 0.4^{f}$ & - \\
\hline C & $69.2 \pm 3.6^{b}$ & 61.8 & $12 \pm 1.4^{\mathrm{bc}}$ & 49.2 & $18.4 \pm 0.4^{b}$ & 22.3 & $7.9 \pm 0.2^{\mathrm{bcd}}$ & 20 \\
\hline $\mathrm{CU}$ & $74.3 \pm 1.4^{\mathrm{a}}$ & 64.5 & $14 \pm 0.2^{a}$ & 56.4 & $21.6 \pm 0.8^{\mathrm{a}}$ & 33.8 & $9.5 \pm 0.3^{a}$ & 32.6 \\
\hline$P$ & $63.5 \pm 2^{c}$ & 58.4 & $13.6 \pm 0.1^{a}$ & 55.1 & $17.8 \pm 0.7^{\mathrm{bc}}$ & 19.7 & $8.5 \pm 0.2^{b}$ & 24.7 \\
\hline S & $57 \pm 1.5^{d}$ & 53.7 & $11.8 \pm 0.4^{c}$ & 48.3 & $15.4 \pm 0.3^{d}$ & 7.1 & $7.3 \pm 0.3^{\text {de }}$ & 12.3 \\
\hline$N+C U$ & $65.9 \pm 1.3^{b c}$ & 59.9 & $13 \pm 0.6^{\mathrm{ab}}$ & 53.1 & $17.4 \pm 0.6^{c}$ & 17.8 & $8.2 \pm 0.9^{b c}$ & 22 \\
\hline$N+P$ & $58.4 \pm 1.8^{d}$ & 54.8 & $11.1 \pm 0.3^{c}$ & 45 & $15.6 \pm 1^{d}$ & 8.3 & $7.5 \pm 0.4^{\text {cde }}$ & 14.7 \\
\hline$N+S$ & $49.9 \pm 2.3^{e}$ & 47.1 & $9.1 \pm 0.5^{d}$ & 33 & $14.9 \pm 0.2^{\mathrm{de}}$ & 4 & $6.9 \pm 0.2^{\mathrm{ef}}$ & 7.2 \\
\hline LSD & 3.6 & & 1.1 & & 1 & & 0.7 & \\
\hline
\end{tabular}

${ }^{\mathrm{x}} N, M$. incognita; $C$, untreated control; $C U$, culture broth; $P$, cell pellet; $S$, supernatant; $N+C U, M$. incognita + culture broth; $N+P, M$. incognita + cell pellet; $N+S$, M. incognita + supernatant

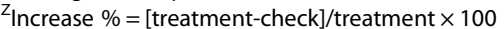

*Means in each column followed by the identical letter do not differ significantly at $P<0.05$ level

representing cell growth and glucose consumption from the culture broth. The reason for decreasing the dissolved oxygen refers to increase in $\mathrm{O}_{2}$ demand for culture growth (Fig. 12). To guarantee a sufficient oxygen supply, oxygen was kept above $20 \%$ by raising the agitation speed from 200 to $500 \mathrm{rpm}$. After $10 \mathrm{~h}$, the dissolved oxygen increased gradually. Matar et al. (2009) maximized biomass and activity of cell-free supernatant of B. subtilis isolate G-GANA7, using batch fermentation in bioreactor.

All treatments of culture broth, cell pellet suspension, and cell-free supernatant of B. subtilis isolate B10 were able to reduce number of galls and egg masses in the roots of tomato plants. Treatment using culture broth in a soil infected with $M$. incognita was highly significant that decreased number of galls and egg masses to reach the average of 9.3 and 6.7 with reduction percentages of
81.1 and $89.5 \%$, respectively, than the treatment with $M$. incognita only whereas number of galls and eggs masses recorded an average of 49.3 and 64, respectively. In the treatment of using cell pellet suspension, number of galls and egg masses reached the average of 18 and 10 with reduction percentages of 63.5 and $84.4 \%$, respectively, while treatment using supernatant was less effective in decreasing number of galls and egg masses, which reached the averages of 27 and 21 with reduction percentages of 45.2 and $67.2 \%$, respectively (Table 1 ). Siddiqui (2002) and Mokbel (2013) reported that bacterial cell free-filtrates of $B$. subtilis isolates was less effective in reducing $M$. javanica and $M$. arenaria multiplication on infected tomato plants than treatment by sporulated bacterial cells suspension that was highly significant. Treatment with culture broth of $B$. subtilis isolate B10 was efficient in the induction and stimulation

Table 3 Effect of formulated Bacillus subtilis isolate B10 on number of galls and egg masses of Meloidogyne incognita occurrence in the roots of tomato plants

\begin{tabular}{|c|c|c|c|c|}
\hline Treatment $^{x}$ & Number of galls & Reduction ${ }^{Y} \%$ & Egg masses & Reduction ${ }^{Y} \%$ \\
\hline $\mathrm{N}$ & $39.7 \pm 2.1^{\mathrm{a}^{*}}$ & 0 & $24.3 \pm 1.2^{\mathrm{a}}$ & 0 \\
\hline C & $0 \pm 0^{f}$ & - & $0 \pm^{f}$ & - \\
\hline F1 & $0 \pm 0^{f}$ & - & $0 \pm^{f}$ & - \\
\hline $\mathrm{F} 2$ & $0 \pm 0^{f}$ & - & $0 \pm^{f}$ & - \\
\hline F3 & $0 \pm 0^{f}$ & - & $0 \pm^{f}$ & - \\
\hline$N+F 1$ & $24.3 \pm 1.2^{b}$ & 38.7 & $14.3 \pm 1.2^{b}$ & 41.1 \\
\hline$N+F 2$ & $16.3 \pm 0.6^{c}$ & 58.8 & $10.3 \pm 0.6^{c}$ & 57.5 \\
\hline$N+F 3$ & $12 \pm 1^{d}$ & 69.7 & $7 \pm 1^{d}$ & 71.2 \\
\hline $\mathrm{N}+$ Vydate & $4.7 \pm 0.6^{\mathrm{e}}$ & 88.2 & $2.7 \pm 0.6^{\mathrm{e}}$ & 89 \\
\hline LSD & 1.5 & & 1.2 & \\
\hline
\end{tabular}

$\overline{\mathrm{x}}_{N}$, M. incognita; $C$, untreated control; $F 1$, formulation $0.02 \mathrm{~g} /$ pot; $F 2$, formulation $0.06 \mathrm{~g} /$ pot; $F 3$, formulation $0.1 \mathrm{~g} /$ pot; $N+F 1, M$. incognita + formulation $0.02 \mathrm{~g} /$ pot; $N+F 2, M$. incognita + formulation $0.06 \mathrm{~g} /$ pot; $\mathrm{N}+\mathrm{F} 3, M$. incognita + formulation $0.1 \mathrm{~g} / \mathrm{pot}$

${ }^{\mathrm{Y}}$ Reduction \% $=$ [check-treatment]/check $\times 100$

*Means in each column followed by the identical letter do not differ significantly at $P<0.05$ level 
the growth of tomato plants in comparison with the other treatments. Fresh and dry weights of both shoots and roots were determined (Table 2). The treatment of using the culture broth in a soil infected with M. incognita encouraged the growth of both shoots and roots of tomato plants, fresh weight of shoots and roots reached $65.9 \mathrm{~g}$ and $17.4 \mathrm{~g}$ with increase of $59.9 \%$ and $17.8 \%$, respectively, whereas dry weight reached $13.03 \mathrm{~g}$ and $8.2 \mathrm{~g}$ with an increase of 53.1 and $22 \%$, respectively. In the treatment with culture broth only, fresh weight of shoots and roots reached 74.3 and $21.6 \mathrm{~g}$ with increase of 64.5 and $33.8 \%$, respectively, while dry weight reached $14.03 \mathrm{~g}$ and $9.5 \mathrm{~g}$ with increase of 56.4 and $32.6 \%$, respectively, than the control. Similar results were obtained by Mokbel and Alharbi (2014) and Xiong et al. (2015).

B. subtilis isolate B10 was formulated and applied as bionematicide versus the treatment of Vydate (nematicide) as a standard to test its efficiency in reducing number of galls and egg masses in the roots of tomato plants caused by $M$. incognita under greenhouse conditions. Treatment with formulated B. subtilis isolate B10 at a concentration of $0.1 \mathrm{~g} /$ pot in a soil infected with $M$. incognita was more significant and effective in reducing number of galls and egg masses than the other concentrations of formulation that were closed to Vydate effect. Number of galls and egg masses decreased to reach the average of 12 and 7 with reduction percentages of 69.7 and $71.2 \%$, respectively, while the treatment of using Vydate decreased number of galls and egg masses to reach the averages of 4.7 and 2.7 with reduction percentages of 88.2 and $89 \%$, respectively, than the treatment with $M$. incognita only; hence, number of galls and egg masses recorded the average of 39.7 and 24.3, correspondingly (Table 3). Burkett-Cadena et al. (2008) documented that Equity ${ }^{\circ}$, BioYield $^{\circ}$ and RhizoVital $^{\circ}$ formulations reduced number of galls per plant on tomato.

\section{Conclusion}

In conclusion, biocontrol agents can be used as an alternative approach of the chemical nematicides for controlling various nematodes. B. subtilis is recommended for the management of root-knot nematode, $M$. incognita. However, further investigations are required to determine the formulation that can achieve the best results.

\section{Acknowledgements}

The authors thank Prof. Ibrahim, I.K.A. and Prof. El-Saeedy, A. at Plant Pathology Department, Faculty of Agriculture, Alexandria University, El-Shatby, Alexandria, Egypt. Also, Prof. Hafez, E.E. and Dr. Kenawy, A.M. at City of Scientific Research and Technological Applications, Alexandria, Egypt for their critical reading and revision.

Funding

Not applicable
Availability of data and materials

All data and material are available.

Authors' contributions

All authors read and approved the final manuscript.

Ethics approval and consent to participate

Not applicable.

Consent for publication

Not applicable

Competing interests

The authors declare that they have no competing interests.

\section{Publisher's Note}

Springer Nature remains neutral with regard to jurisdictional claims in published maps and institutional affiliations.

\section{Author details}

${ }^{1}$ Plant Pathology Department, Faculty of Agriculture, University of Alexandria, El-Shatby, Alexandria, Egypt. ${ }^{2}$ Bioprocess Development Department, Genetic Engineering and Biotechnology Research Institute, City of Scientific Research and Technological Applications, Universities and Research Center, New Borg El-Arab City, Alexandria, Egypt.

Received: 16 June 2018 Accepted: 31 October 2018

Published online: 20 November 2018

\section{References}

Asaka O, Shoda M (1996) Biocontrol of Rhizoctonia solani damping-off of tomato with Bacillus subtilis RB14. Appl and Envir Micro 62:4081-4408

Burkett-Cadena M, Kokalis-Burelle N, Lawrence KS, Santen EV, Kloepper JW (2008) Suppressiveness of root-knot nematodes mediated by rhizobacteria. Biol Control 47:55-59

Castaneda-Alvarez C, Aballay E (2016) Rhizobacteria with nematicide aptitude: enzymes and compounds associated. World J Microb Biotech 32:203

Chen L, Jiang H, Cheng Q et al (2015) Enhanced nematicidal potential of the chitinase pachi from Pseudomonas aeruginosa in association with Cry21Aa. Sci Rep 5:14395

Collee JG, Fraser AG, Marmion BP, Simmons A (1996) Practical medical microbiology. Tests for the identification of bacteria, 14th edn. Churchill Livingstone, New York, pp 131-149

Csuzi S (1978) The induction of a lytic enzyme in cultures of Bacillus cereus. Acta Biochim Biophys Acad Sci Hungaria 13:41-42

Gray EJ, Lee KD, Souleimanov AM, Falco MRD, Zhou X, Charles TC, Driscoll BT, Smith DL (2006) A novel bacteriocin, thuricin 17, produced by plant growth promoting rhizobacteria strain Bt NEB17: isolation and classification. J Appl Microbiol 100:545-554

Holbrook CC, Knauft DA, Dikson DW (1983) A technique for screening peanut for resistance to Meloidogyne arenaria. Plant Dis 57:957-958

Huang WK, Cui JK, Liu SM, Kong LA, Wu QS, Huan Peng H, He WT, Sun JH, Peng DL (2016) Testing various biocontrol agents against the root-knot nematode (Meloidogyne incognita) in cucumber plants identifies a combination of Syncephalastrum racemosum and Paecilomyces lilacinus as being most effective. Biol Control 92:31-37

Kavitha PG, Jonathan El, Nakkeeran S (2012) Effects of crude antibiotic of Bacillus subtilis on hatching of eggs and mortality of juveniles of Meloidogyne incognita. Nematol Medit 40:203-206

Khan Z, Kim SG, Jeon YH, Kh HU, Son SH, Kim YH (2008) A plant growth promoting rhizobacterium, Paenibacillus polymyxa strain GBR-1, suppresses root-knot nematode. Bioresour Technol 99:3016-3023

Matar SM, El-Kazzaz SA, Wagih EE, El-diwany Al, Hafez EE, Moustafa HE, Abo-Zaid GA, Serour EA (2009) Molecular characterization and batch fermentation of Bacillus subtilis as biocontrol agent, II. Biotechnology 8:35-43

Mokbel AA (2013) Impact of some antagonistic organisms in controlling Meloidogyne arenaria infecting tomato plants. J Life Sci Tech 1:69-74

Mokbel AA, Alharbi AA (2014) Suppressive effect of some microbial agents on root-knot nematode, Meloidogyne javanica infected eggplant. Aust J Crop Sci 8:1428-1434 
Oka Y, Kolta H, Bar-Eyal M, Mor M, Sharon E, Chet I, Spiegel Y (2000) New strategies for the control of plant-parasitic nematodes. Pest Manag Sci 56: 983-988

Page AP, Stepek G, Winter AD, Pertab D (2014) Enzymology of the nematode cuticle: a potential drug target. Int J Parasitol Drugs Drug Resist 4:133-141

Prakob W, Nguen-Hom J, Jaimasit P, Silapapongpri S, Thanunchai J, Chaisuk P (2009) Biological control of lettuce root knot disease by use of Pseudomonas aeruginosa, Bacillus subtilis and Paecilomyces lilacinus. J Agric Tech 5:179-191

Siddiqui A (2002) Suppression of Meloidogyne javanica by Pseudomonas aeruginosa and Bacillus subtilis in tomato. Nema Mediterr 30:125-130

Sneath PHA, Mair NS, Sharpe ME, Holt JG (1986) Bergey's manual of systematic bacteriology. In: Endospore-forming gram-positive rods and cocci, vol 2. Williams and Wilkins, Baltimore, pp 1104-1139

Stirling GR (1991) Biological control of plant parasitic nematode: progress, problems and prospects. CAB International, Wallington

Xiao TJ, Tan SY, Shen QR, Ran W (2012) Bacillus cereus X5 suppresses root-knot nematode of tomato by colonizing in roots and soil. Afr J Microbiol Res 6: 2321-2327

Van Dam-Mieras MCE, Jeu WH, Vries J, Currell BR, James JW, Leach CK, Patmore RA (1992) Techniques used in bioproduct analysis. Butterworth-Heinemann Ltd., Oxford, p 16

Vidhyasekaran P, Muthamilan M (1995) Development of formulation of Pseudomonas fluorescens for control of chickpea wilt. Plant Dis 79:782-786

Wepuhkhulu M, Kimenju J, Anyango B, Wachira P, Kyallo G (2011) Effect of soil fertility management practices and Bacillus subtilis on plant parasitic nematodes associated with common bean, Phaseolus vulgaris. Trop Subtrop Agro Ecosyst 13:27-34

Yeh M, Wei Y, Chang J (2006) Bioreactor design for enhanced carrier-assisted surfactin production with Bacillus subtilis. Process Biochem 4:1799-1805

\section{Submit your manuscript to a SpringerOpen ${ }^{\circ}$ journal and benefit from:}

- Convenient online submission

- Rigorous peer review

- Open access: articles freely available online

- High visibility within the field

- Retaining the copyright to your article

Submit your next manuscript at $\boldsymbol{\nabla}$ springeropen.com 